\title{
The Universality of the Universal Declaration of Human Rights: Does it merely express Western Values?
}

\author{
Syaiful Anam \\ International Relations Department, Universitas Mataram, Nusa Tenggara Barat, Indonesia \\ Email: s.anam@unram.ac.id \\ Submitted: 6 October 2017 | Accepted: 17 May 2018
}

\begin{abstract}
The debate over the universality of Universal Declaration of Human Rights remains taking place. Apart from the fact that the document remains popular and has been encouraged by many countries around the world. The debate revolves around values and cultural differences among countries claiming that Western values have been predominating the content of the declaration itself. This essay argues that the dispute towards the universality of UDHR would likely form a robust standard and values of internationally recognized human rights as long as a cross-cultural and cross-philosophical talk could be encouraged.
\end{abstract}

Keywords: Human Rights, Cultural, Difference, Universality.

\begin{abstract}
Abstrak
Perdebatan mengenai universalitas Deklarasi Universal tentang Hak Asasi Manusia masih terus tetap berlangsung. Terlepas dari fakta bahwa deklarasi tersebut masih populer dan telah didorong oleh banyak negara di seluruh dunia, perdebatan tersebut berkisar pada nilai dan perbedaan budaya di antara negara-negara yang mengklaim bahwa nilai-nilai Barat mendominasi isi deklarasi itu sendiri. Esai ini berargumen bahwa perdebatan terhadap universalitas Deklarasi Universal Hak Asasi Manusia membentuk standar dan nilai yang kuat dari hak asasi manusia yang diakui secara internasional selama ada dorongan untuk dibahas secara lintas budaya dan filosofis.
\end{abstract}

Kata Kunci: Hak Asasi Manusia, Perbedaan, Kutural, Universalitas.

\section{INTRODUCTION}

Considering the need for applying universal principle of justice throughout nation-states, cosmopolitan scholars attempt to fortify the universality of human rights. This concept has institutionalized and disseminated through the creation of innumerable human rights organizations in order to advocate a noble task in upholding human rights values in whole part of the world and in preventing human rights violations. However, the universality of human rights is not accepted by all nations. Some countries regard that human rights is merely a form of Western ideological imperialism imposed to them. Others reject it because of its values are not compatible with the religion tenets. 
The debate over the universality of human rights in this essay focusing on the Universal Declaration of Human Rights (UDHR), which many argue that it is predominantly expressing the Western values and thus it is a form of Western imperialism. It will discuss both side arguments pro and against the universality of human rights within the UDHR. The first part of the essay will then explore the historical background of the Universal Declaration of Human Rights. The next part of the essay will be continue with discussion of the dispute upon the universality of UDHR. The discussion will finally go on to the conclusion that the dispute towards the universality of UDHR would likely form a robust standard and values of internationally recognized human rights as long as a cross-cultural and cross-philosophical talk could be encouraged.

\section{THE UNIVERSAL}

\section{DECLARATION OF HUMAN RIGHTS}

The modern conception of human rights created by the United
Nations (UN) emerged as the consequence of war and conflict. Human atrocities during the World War first and second have caused massive human rights violation, meanwhile at that moment there were no one universal human rights values existed. It is true that there had been certain declarations regarding human rights prior to World War II, such as the Bill of Rights, and the Declaration of the Rights of Man and of the Citizen, but it did not represent the universal values of human rights. As a result, two years after the establishment of the UN, the UN's Secretary General, Trygve Lie, requested the draft for human rights declaration. Humprey, Saint-Lot, Roosevelt, and other drafters then drafted the first of UN Document for Human Rights. These drafters, as many people believe, have an intellectual genealogy based on Western historical progress (Spickard, 1999). Hence, it does not be surprising if the concept of UDHR is constituted by codes from Western historical experiences such as the Magna Charta 
(1215), the Glorious Revolution (1668), Thomas Jefferson's Declaration of Independence (1776), the US Bill of Right (1789) and as well as the thought from philosophers such as John Locke and Voltaire, who advocated the dominance of reason, science, and natural rights. These all becomes the foundation of modern human rights value and doctrine in UDHR claimed to be universally accepted and relevant.

The claim of universality in UDHR based on its aim that endeavors to protect the rights of human being regardless the race, religion, nationality, socio-economic status, gender, and other differences. Human rights related to the human dignity which others cannot undermine or humiliate this dignity. Human rights as well as human dignity are an inherent characteristic of human being and thus it is immutable. These rights hence function as the basis for the human equality and justice in all over the world. All human beings deserve human rights, as it is asserted by Freeman (2002) who argues that certain rights is given to all human purely because they are being human. This idea and doctrine thus justify the universality of human rights. In addition, the expression of the universality of human rights in UDHR showed also through the ratification of at least one of the nine core international human rights treaties by all member states of the United Nations (the Universal Declaration of Human Rights, 2012).

Given that human rights as universal concept and value, the United Nation approved the draft of the Universal Declaration of Human Rights that was proclaimed and adopted on 10 December 1948 by the General Assembly resolution 217 A (III). The main point of UDHR is about the idea that people have basic human rights as human being such as right to life, security, liberty, right to equal before the law; and constitute of freedom from fear, slavery and torture. The recognition of these rights is not because of the certain citizen status, but it is based on that they are human beings. Thus, the main concern of 
UDHR itself is to encourage human rights and freedoms to be respected and guaranteed universally, as well as to monitor the process of both recognition and violation these human rights and freedoms.

Moreover, this is noteworthy that UDHR is a document reflects the intersection between morality and law. Law thus functions to protect human rights, which mean also to preserve human dignity. This notion based on the article 1 of UDHR 1948, states that "all human beings are born free and equal in dignity and rights". It is strengthened also by the article 11, states, "everyone charged with a penal offence has the right to be presumed innocent until proved guilty according to law in a public trial at which he has all the guarantees necessary for his defence". Through the ratification of international human rights treaties, governments set certain legal system and measures in order to implement the treaties in domestic level. Hence, through this domestic legal system, the principal of human rights is protected and is guaranteed as well under the international law. In case of domestic legal system failed in preventing human rights abuses, mechanisms and procedures can be requested either by individual or group to complaint these abuses through the regional and international levels which guarantee that the standard of international human rights are respected and implemented at the local level (the Universal Declaration of Human Rights, 2012). Therefore, it shows, through the role of international law, that human rights are not only universal, but also indeed this universality preserved by certain legal system and mechanism.

\section{DISCUSSION}

\section{THE UNIVERSALITY OF UDHR: DOES IT MERELY EXPRESS WESTERN VALUES?}

The universality of human rights, particularly of UDHR, are still highly debated by many who maintain that the UDHR and its international human rights norms are solely formulated by the West and hence it does not compatible for all nations. Many scholars argue that the Western 
Europe and North American values predominantly represented in UDHR and hence it tends to be biased upon other values such as the values of Asia, Africa and Latin America. The rejection upon the universality of international human rights, for instance, happened at the World Conference on Human Rights in Vienna in 1993.

The debate was centered on the cultural differences between Asian values and Western values that were stressed by several delegations from Asia. It has warned by the Singapore foreign minister, "Universal recognition of the ideal of human rights can be harmful if universalism is used to deny or mask the reality of diversity". This also emphasized by the Chinese delegation who asserted that there should be a room for preserving the diversity in human rights (Sen, 1997). In addition, Kausikan $(1993,26)$ argues that what it should be focused regarding the problem of the universality of human rights values is that the reality of diverse cultural traditions, political structures, and level of development, particularly in Asia region, will put international human rights itself to be difficult or even impossible in defining a single distinctive and coherent human rights regimes that can cover this enormous region which include its Confucianist, Buddhist, Islamic, and Hindu traditions. Although certain attempts have been continued in order to counter this challenge, throughout Asian region is still unsatisfied with a simply Western interpretation of human rights. Kausikan points out that further development in Asia region will be formed by its internal developments, yet this would consequently encounter pressures from the United States and Europe.

Another issue that questions the universality of international human rights values related to the origin of UDHR. Many scholars argue that the document of UDHR itself constituted by the codes, ethics, and values came from the Western ideology and experience and hence the Document cannot be regarded as universal. The Communist China, for instance, 
questions the notion of the relationship between state and the individual. The human rights values within UDHR are underpinned by the notion of Western's individualism that is not compatible to the China's values. Here, Chinese foreign minister suggested a proposition that could be applicable not only in China, but also in elsewhere, that "Individuals must put the states' rights before their own" (Sen, 1997). In addition to the discontent of UDHR's origin, the critique comes from the Moslem. For example, "Saudi Arabia rejected the Declaration's commitment to freedom of religion, as threatening to their country's constitutional religious setup" (Villa-Vicencio, 1992, 118). It is also reiterated by Spickard (1999) that the delegation of Saudi Arabian rejects the point in UDHR regarding the point of freedom to change one's religion, because it is absolutely prohibited by the Qur'an except for others non-Moslem. Moreover, Saudi Arabian worried upon the impact of this right which would open wider chance to Western missionaries in the
Middle East and thus it would disrupt the religious stability in the region. Other countries such as Afghanistan, Egypt, Iraq, Pakistan, and Syria gave their support for the Saudi Arabia's rejection in the General Assembly.

Another proposition challenges the universality of UDHR and international human rights concerns to the fact that the document indeed cannot bind all nations. Villa-Vicencio contends that "the Declaration is not itself a law, but a set of prima facie ideas, and has only been worked into international law through later U.N. Covenants that were signed as treaties, and which contained similar articles" (1992, 119). In fact, the Declarations' commitment did not reflect the universal point of view that can bind states altogether in respecting and advocating it as a document that is universally accepted. Rather, it is merely a commitment created under the interest of Western countries. It is as Nickel (Nickel, 1987, 46) argues, that "the modern conception of human rights developed in the aftermath of the Second World War, in 
part as a response to the Holocaust, culminating in the signing of the Universal Declaration of Human Rights by the United Nations General Assembly". Therefore, these all cast a doubt upon the universality of UDHR and its human rights conception and values to other non-western cultures and nations.

Apart from many rejection of the universality of UDHR, the document remains popular and has been encouraged by many countries around the world. This accomplishment would not be attained without the key role of the United Nations (UN), which has framed and disseminated the concept. Pakistan, which at the first time stood for Saudi Arabian, had ultimately changed its stance to challenge the value and regional bias came from the Muslim countries. Pakistan's position to fight against teror is a clear gesture of its acceptance upon the universality of UDHR. If the fact that the declaration can be applied and does relevant to other nonWestern states, thus it reflects that the declaration is universal.
It is also argued by most scholars that the historical process precisely prove that societies and cultures in all over the world had practiced the universality of human rights. As outlined by Pollis and Schwab (Pollis, $1979,3)$ that "All societies crossculturally and historically manifest conceptions of human rights. Such activities became part of their customs and traditional values, which were later transformed into constitutional sources, and have today, formed the backbone of their modern constitutions", thus all input that given to the draft until the declaration of UDHR shaped by the universal values and doctrine that advocated by all nations around the globe.

Proponent of the universality of human rights, such as Taylor (1999), suggests that human rights as a universal concept and an unforced international consensus gained through John Rawls' insight on an "overlapping consensus". It outlines that although different groups and communities advocate different religious tenet, values, and 
philosophical commitments, they could possibly achieve certain norms that is acknowledged altogether and is believed could govern their conduct. Jack Donelly (2003) outlines further insight regarding John Rawls' overlapping consensus. Donelly argues that the idea of overlapping consensus can be found within the Document of UDHR. Donelly holds that the idea of overlapping consensus in fact brings the universality of human rights into the Document of Declaration. He points out that "the claim is that most leading elements in almost all contemporary societies endorse the idea that every human being has certain equal and inalienable rights and is thus entitled to equal concern and respect from the stateand that what holds this otherwise disparate group together is a fundamental commitment to human equality and autonomy" (Donelly, 2003, 51). What Donelly tries to emphasize here is regarding the structure in the society. He states that:

"Social structure, not "culture," does the explanatory work. When the West was filled with "traditional societies," it had social and political ideas and practices strikingly similar to those of traditional Asia, Africa, and the Near East.

Conversely, as those regions and civilizations have been similarly penetrated by modern markets and states, the social conditions that demand human rights have been created. This is the foundation of the overlapping consensus on and the contemporary moral universality of human rights" (Donelly, 2003, 78).

The main point here is in the notion of "modern markets and states" which have influenced the social condition to demand upon the creation of human rights. This means that modern markets and states are doing their role in explaining the need of society for human rights. Thus, it leads to a plausible reason, as explained by On (2005), that "the same threats from modern markets and states would consequently demand the same protections of human rights that are available not only to individuals in the West, but also must be made available to individuals outside the West". In regard to this point, Donelly stresses his view that "the thrust of my argument will be that contemporary Asian individuals, families, and 
societies face the same threats from modern markets and states that Western societies do, and therefore need the same protections of human rights" (Donelly, 1999, 69). However, Donelly's insight becomes an odd since he acknowledged that the internationally recognized human rights have various ways in its implementation and interpretation (Donelly, 2003, 89). If this is the case, it could be that the Asian human rights protection would be different as in the West, and thus it turns back to the main debate whether or not human rights universally accepted and recognized by all states and societies around the globe.

\section{CONCLUSION}

This essay would like to conclude that rejection upon the universality of human rights, particularly the universality of UDHR, would likely continue as long as the norms and values within the current international human rights are not accommodating other non-Western cultures. It is not an easy task, yet the way can be found.
Concerning this problem, at last, it would suggest, as claimed by Abdullahi An-Na'im, “only by encouraging cross-cultural and crossphilosophical conversations can one arrive at universally agreed-upon human rights standards. These standards will not reflect any one philosophy, but will reflect an emerging transnational consensus of the way social life ought to be ordered" (Spickard, 1999, 8).

\section{BIBLIOGRAPHY}

Donelly, J. (1999) Human Rights and Asian Values: A Defense of 'Western' Universalism, in Joanne R. Bauer and Daniel A. Bell (eds), The East Asian Challenge for Human Rights, United Kingdom: Cambridge University Press.

Donelly, J. (2003) Universal Human Rights: In Theory and Practice, 2d. ed, Ithaca, New York: Cornell University Press.

Freeman, M. (2002) Human Rights, United Kingdom: Polity Press.

Kausikan, B. (1993) “Asia's Different Standard”, Foreign Policy, No. 92, p 2441.

Nickel, JW. (1987) Making Sense of Human Rights, Berkeley: University of California Press.

On, S. (2005) The "Relative Universality" of Human Rights: An Assessment, Perspectives on Global Development and Technology, Volume 4, issue 3-4, p 577 601. 
Pollis, A and Schwab, P (Ed.). (1979) Human Rights: Cultural and Ideological Perspectives, New York: Praeger Publishers.

Sen, A. (1997) Human Rights and Asian $V$ alues (Online). Available at: https://www.mtholyoke.edu/acad/int $\mathrm{rel} / \mathrm{sen} . \mathrm{htm}$ (Accessed: 21 March 2018).

Spickard, JV. (1999) The Origins of the Universal Declaration of Human Rights [Online]. Available at: http://newton.uor.edu/FacultyFolder /Spickard/OnlinePubs/OriginUDHR .pdf (Accessed: 31 Februari 2017).

Taylor, C. (1999) Conditions of an Unforced Consensus on Human Rights. In Joanne R. Bauer and Daniel A. Bell (eds), The East Asian Challenge for Human Rights. United Kingdom: Cambridge University Press.
The United Nations. (2007) Universal Declaration of Human Rights (Online). Available at: http://www.un.org/events/humanrig hts/2007/hrphotos/declaration $\% 20$ eng.pd $\mathrm{f}$ (Accessed: 16 December 2017).

The United Nations. (2012) The Universal Declaration of Human Rights (Online). Available at:

http://www.un.org/en/documents/u dhr/drafters.shtml (Accessed: 16 December 2017).

Villa-Vicencio, C. (1992) A Theology of Reconstruction: Nation-Building and Human Rights, United Kingdom: Cambridge University Press. 